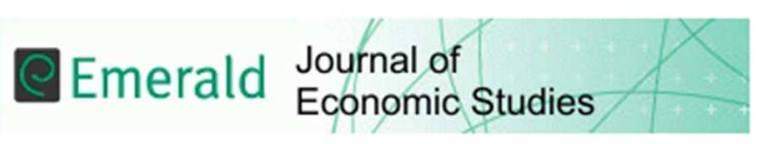

\title{
New evidence on corruption and government debt from a global country panel: a non-linear panel long-run approach
}

\begin{tabular}{|r|l|}
\hline Journal: & Journal of Economic Studies \\
\hline Manuscript ID & JES-03-2018-0088.R1 \\
\hline Manuscript Type: & Research Paper \\
\hline Keywords: & corruption, shadow economy, government debt, 120 countries, panel data \\
\hline \multicolumn{2}{|l}{} \\
\hline
\end{tabular}

SCHOLARONE $^{\text {m }}$

Manuscripts 


\title{
New evidence on corruption and government debt from a global country panel: a non-linear panel long-run approach
}

\begin{abstract}
Purpose - This paper explores the link between corruption and government debt through a regime-based approach.

Design/methodology/approach - The empirical analysis makes use of a panel of 120 countries, spanning the period 1999-2015. The study makes use of the Panel Smooth Transition Regression (PSTR) methodological approach, as well as two alternative measures of corruption.

Findings - The empirical results document that the relationship between corruption and debt is non-linear, while a strong threshold effect was present as well. Public debt appears to respond faster to a high corruption regime compared to a low corruption regime, while an increase in the size of the shadow economy, government expenses, the inflation rate, interest payments on debt and military expenditure all increased the debt to GDP ratio. By contrast, an increase in GDP per capita, the secondary school enrollment ratio and the ratio of tax revenues to GDP led to a fall in the debt to GDP ratio. The findings survive certain robust checks when the role of the 2008 financial crisis is explicitly considered, as well as when two separate country samples were considered, i.e. developed vs developing countries.

Practical implications - Governments should aim to control both corruption and the size of the shadow economy if they really wish to reduce any high levels of their public debt. As debt levels respond faster to high corruption regimes, it is necessary that measures to reduce corruption are complemented by higher GDP per capita growth rates, enrolment rates and higher tax revenues.

Originality/value - The major novelty of the paper is that it investigates for the first time the likely presence of non-linearity between corruption and government debt, by using a PSTR methodological framework. It proposes non-linear panel cointegration and causality tests, as well as a non-linear panel error correction model that allows for smooth changes between regimes, hence, examining causal relationships in each regime separately.
\end{abstract}

Keywords: corruption; shadow economy; government debt; 120 countries; panel data JEL Classification: E6; H63; C33

Paper type: Research paper 


\section{Introduction}

The effects of corruption on public debt have been investigated by Cooray et al. (2017). They use a panel of 126 countries and show that corruption adversely affects public debt, while the extent of the shadow economy exacerbates this relationship. We extend upon the study of Cooray et al. (2017) by using the Panel Smooth Transition Regression (PSTR) model of González et al. (2005) to examine potential threshold effects in the relationship between debt and corruption. The main novelty of the paper is that it investigates the presence of non-linearity between corruption and government debt by using a non-linear panel cointegration methodology, as well as a non-linear panel error correction model that allows for smooth changes between regimes. The non-linear estimations can provide insight on whether the relationship between corruption and public debt changes over different states of corruption. While Cooray et al. (2017) investigate for non-linearity in the debt-corruption relation, by using quadratic terms, the PSTR model is particularly useful when the non-linear dynamics are attributed to a common regime-switching component, especially when the reaction to this component may differ across variables. This method allows us to relax the restricting assumption of a constant adjustment toward equilibrium. The PSTR methodology takes explicitly into account heterogeneity by allowing regression coefficients to change as a function of an exogenous variable and to fluctuate across regimes. As the transition variable is individual-specific and time varying, the regression coefficients for each of the individuals in the panel are changing over time. Additionally, this approach permits smooth changes in country-specific associations, depending upon a threshold. Discovering regime-dependent interactions across the variables under investigation is highly significant for designing regulatory policies.

There has been abundance in the literature exploring the role of corruption ${ }^{1}$ in the economy. In particular, corruption has been shown to been detrimental to growth (Mo, 2001; Tanzi and Davoodi, 2002), foreign direct investment (Wei, 2000; Abed and Davoodi, 2002), productivity (Lambsdorff, 2003), inflation (Al-Marhubi, 2000), confining the shadow economy (Friedman et al., 2000; Schneider et al., 2010), government bond ratings (Depken and Lafountain, 2006), government expenses on

\footnotetext{
${ }^{1}$ Corruption is defined as the abuse of public power for private gains (Buehn and Schneider, 2009).
} 
education and health (Mauro, 1998), and the economic status of the poor (Justesen and Bjornskov, 2014).

By contrast, certain studies argue that the presence of corruption could be efficiency improving for the economy. Leff (1964), Johnson (1975), Wedeman (1997) and Liu (1996) present evidence that corruption reduces bureaucracy, thus leading to higher economic growth, while Aidt (2009) and Meon and Weill (2010) display that this growth effect of corruption depends on the institutional environment in the economy. Dzhumashev (2014) illustrates that the link between corruption and governance determines the efficiency of public expenses, and, hence, the abovementioned growth effect of corruption.

At the same time, the relationship between corruption and the shadow economy has been explored by two schools of thought. Tanzi (1998) supports the first approach and argues that those who evade taxes are considered to be part of the shadow economy, while the second approach supports that the absence of solid institutions in the economy, i.e. higher levels of corruption results in a enhanced shadow economy (Dreher et al., 2009). In contrast, Friedman et al. (2000) argue that corruption and the shadow economy do not have to act in a substitute manner, but complementarily, given that weak institutions and enhanced corruption drive individuals and firms underground. His arguments have found solid empirical support extensively in the literature (Schneider and Enste, 2000; Dreher and Schneider, 2010, Kaufmann, 2010). However, only a limited literature examines the issue of how corruption impacts government debt. Johnson et al. (1997) and Friedman et al. (2000) provide evidence to the question on the fact that tax evasion undermines governments' ability to provide public goods, thus, making them turn to more intensive borrowing activities, leading to a vicious cycle of corruption and borrowing.

Corruption can affect a government's budget balance and government debt through a number of transmission mechanisms. The budget balance has implications for the level of government debt $^{2}$. Budget deficits (surpluses) are associated with increasing (decreasing) levels of public debt. If a government runs a budget deficit, it will borrow an amount equal to the size of the deficit. Governments can borrow by selling government bonds which will lead to a rise in the level of public debt. Corruption can increase public expenses due to rent seeking (Tanzi and Davoodi

\footnotetext{
${ }^{2}$ Note, the stock of government debt at the end of period $t$ is equal to the stock of government debt at the end of period $\mathrm{t}-1$ minus the budget balance (deficit or surplus) in period $\mathrm{t}$.
} 
2002). In corrupt societies, government officials are inclined to demand bribes from those undertaking large scale capital intensive projects (Kaufmann 2010) leading to higher budget deficits and higher issuance of bonds to finance such projects. At the same time, corruption can change the structure of such public expenses and away from sectors such as education and health towards sectors characterized by less transparency and harder monitoring, such as defense expenses (Gupta et al., 2001; Wei, 2001). A government can alternatively increase taxes; however, increasing taxes have economic and political consequences.

Corruption can affect government debt through a number of transmission mechanisms. Tanzi and Davoodi (2002) support that corruption leads to increased public expenses. Kaufmann (2010) argues that government officials are inclined to bribe taking from capital intensive projects; therefore, higher levels of government debt are issued to finance such projects. At the same time, corruption can change the structure of such public expenses and away from sectors such as education and health towards sectors characterized by less transparency and harder monitoring, such as defense expenses (Gupta et al., 2001; Wei, 2001).

We consider a non-linear causal investigation between corruption, and government debt and we are interested in analyzing the corruption-public debt relationship once we depart from the assumption of common parameters across all countries. Studies have indicated that the relationship between corruption and economic activity may well be non-linear (Méndez and Sepúlveda, 2006; Del Monte and Papagni, 2007; Aidt et al., 2008) and vary across regions (Montinola and Jackman, 2002). Theories of multiple equilibria suggest that as more resources are devoted to corruption, the returns to corruption and productivity will fall, and beyond some threshold point, the returns to production will be falling at a faster rate to the returns to corruption, with corruption exhibiting increasing returns (Murphy et al., 1993). It is, therefore, possible to argue that as productivity falls, it leads to an increased need for greater borrowing, particularly in countries which are financially constrained. This could lead to the presence of a number of equilibria between corruption and debt, suggesting that the corruption-debt relationship can vary not only with time, but also according to the type of the regime. Similarly, shocks can give rise to changes in the corruption-debt relationship. Econometrically, it is known that ignoring the impact of cross-section correlation, arising from global shocks or other spillover effects, yields seriously biased estimates for the parameters of interest (Phillips and Sul, 2003; Andrews, 2005), while non-linearities may spuriously appear 
if heterogeneous relationships are erroneously modeled as common across countries (Haque et al., 1999).

As mentioned above, shocks can give rise to changes in the corruption-debt relationship. Therefore, a second contribution of this study is that it also examines the effect of the recent global financial crisis and its potential distorting impact on identifying the debt-corruption economy nexus in the data (cross-section correlation). During recessions, governments may borrow to finance temporarily larger budget deficits associated with the effects of automatic stabilisers and discretionary fiscal policy. A government can alternatively raise taxes and/or reduce government spending; but this would increase the size of the contractionary gap and lead to deeper recession. According to Reinhart and Rogoff (2011), financial and/or banking crises often precede or accompany sovereign debt crises, while Diaz-Alejandro (1985) and Velasco (1987) argue that governments frequently take on massive debts from the private banks, thus, undermining their own solvency. This type of 'twin crises', has been identified by Reinhart and Rogoff $(2009 a, b)$, as largely owing to collapsing revenues, while government debt typically rises significantly in the years following a systemic financial crisis, setting the stage for rating downgrades and, in the worst-case scenario, default. Moreover, the incidence of crisis can also contribute to the incidence of bribery and corruption. In particular, it has been argued that the victims of the economic crisis are more likely to engage in corrupt exchanges than the nonvictims. The explanation is lying on reasons, such as that people hit by an adverse income shock may be more likely to pay bribes to public officials (Pathak et al., 2008; Mistry and Jalal, 2012), or that among all those people who contact public officials, crisis victims may end up paying bribes more frequently than the non-victims because the stress of the change in circumstances makes them more vulnerable to abuse by public officials which can change the corruption-debt relationship. Finally, the empirical analysis is undertaken by dividing the sample into two: developed and the developing countries as corruption is likely to be higher in developing countries (Svensson 2005).

The paper is structured as follows. Section 2 describes the data, while Section 3 presents the methodology employed. Section 4 presents and evaluates the empirical results and, finally, Section 5 concludes.

\section{Data}


The analysis makes use of annual data from 120 countries, spanning the period 19992015. The list of countries can be seen in the Appendix. Their selection was exclusively based on data availability.

The dependent variable is the ratio of public debt to GDP. The primary independent variable is corruption, which is measured through two alternative measures: i) the corruption Perceptions Index made available from Transparency International. The index ranges from 0 (totally corrupt) to 10 (not corrupt). For simplification purposes, the index has been reversed (i.e., 0 stands for not corrupt and 10 for totally corrupt), and ii) the corruption measure recommended by Kaufmann et al. (2013), which ranges from -2.5 (totally corrupt) to 2.5 (totally corrupt). This index has been also scales so that 0 stands for not corrupt and 5 for totally corrupt. Finally, this corruption measure is available only in 1996, 1998, 2000, and 2002 to 2015. For the cases in 1999 and 2001 we made use of the same data from 1998 and 2000, respectively.

Other control variables entering the model procedure are: the size of the shadow economy ${ }^{3}$, given that corrupt economies tend to have larger segments of their shadow parts, thus, experiencing higher government debts (Cooray et al. 2017). Data on the shadow economy come from Schneider et al. (2010). They define the drivers that determine a shadow economy as: i) the overall tax and social security contribution burden, ii) the intensity of regulations, iii) public sector services and iv) the official sector. They measure it by using the Multiple Indicator Multiple Cause (MIMIC) approach to estimate it. Their estimates cover the span 1999-2007. To fill in the missing data, the analysis extrapolates the data. In addition, the modeling approach employs the ratio of government expenses to GDP as a control variable (Tanzi and Davoodi, 2002), GDP per capita, the secondary enrollment ratio (both to measure the development level of the economy), the inflation rate (Al-Marhubi, 2000), tax revenues as a ratio of GDP (Schneider et al., 2010; Kaufmann, 2010), and interest payments on debt as a ratio of GDP (Kaufmann, 2010). Table I reports descriptive statistics. The basic equation of interest for our analysis is described as follows:

$\operatorname{Debt}_{i t}=\beta_{1} x^{\prime}{ }_{i t}+u_{i t}$

\footnotetext{
${ }^{3}$ The shadow economy is defined as 'the market-based production of goods and services that escapes detection in official estimates of GDP' (Smith, 1994).
} 
where $x^{\prime}$ is a vector of all control variables mentioned above, and $u_{i t}=\alpha_{i}+f_{i}+\varepsilon_{i t}$, with $\alpha_{i}$ capturing country-specific intercepts, $f_{i}$ being a set of unobserved common factors, and $\varepsilon_{\mathrm{it}}$ depicting a random error term that captures the effect of all omitted variables.

\section{[Insert Table I about here]}

\section{Methodology}

All the asymptotic theory for the Panel Smooth Threshold Regression (PSTR) model is based on the hypothesis of stationary regressors. Therefore, the procedures of PSTR specification rely on the assumption that all variables in the modeling approach are $\mathrm{I}(0)$ process. In order to analyze stationarity properties of the data, we test whether the data have a unit root. Panel unit root tests of the first-generation can lead to spurious results (because of size distortions), if significant degrees of positive residual crosssection dependence exist and are ignored. Consequently, the implementation of second-generation panel unit root tests is desirable only when it has been established that the panel is subject to a significant degree of residual cross-section dependence. In the cases where cross-section dependence is not sufficiently high, a loss of power might result if second-generation panel unit root tests that allow for cross-section dependence are employed. Therefore, before selecting the appropriate panel unit root test, it is crucial to provide some evidence on the degree of residual cross-section dependence.

The cross-sectional dependence (CD) statistic by Pesaran (2004) is based on a simple average of all pair-wise correlation coefficients of the OLS residuals obtained from standard augmented Dickey-Fuller regressions for each variable in the panel. Under the null hypothesis of cross-sectional independence, the CD test statistic follows asymptotically a two-tailed standard normal distribution. The results uniformly reject the null hypothesis of cross-section independence, providing evidence of cross-sectional dependence in the data given the statistical significance of the CD statistics.

Two second-generation panel unit root tests are employed to determine the degree of integration in the respective variables. The Pesaran (2007) panel unit root test does not require the estimation of factor loading to eliminate cross-sectional dependence. Specifically, the usual ADF regression is augmented to include the lagged cross-sectional mean and its first difference to capture the cross-sectional dependence that arises through a single-factor model. The null hypothesis is a unit 
root for the Pesaran (2007) test. The bootstrap panel unit root tests by Smith et al. (2004) utilize a sieve sampling scheme to account for both the time series and crosssectional dependence in the data through bootstrap blocks. All four tests by Smith et al. (2004) are constructed with a unit root under the null hypothesis and heterogeneous autoregressive roots under the alternative hypothesis. The results of these panel unit root tests are reported in Table II and support the presence of a unit root across all variables under consideration, except in the case of inflation, where the variable turns out to be stationary at its levels.

\section{[Insert Table II about here]}

To detect the potential non-linear relationship between public debt and corruption, we use the PSTR model developed by González et al. (2005). We express the simplest case of a PSTR with threshold one or two extreme regimes and a single transition function to illustrate the relationship between public debt and corruption:

$\operatorname{Debt}_{i t}=\alpha_{i}+\beta_{0} x^{\prime}{ }_{i t}+\beta_{1}{ }^{\prime} x_{i t} F\left(\pi_{i t}, \gamma, c\right)+\varepsilon_{i t}$

where $\mathrm{i}=1 \ldots . \mathrm{N}, \mathrm{t}=1 \ldots \ldots \mathrm{T} ; \mathrm{N}$ and $\mathrm{T}$ denote the cross-section and time dimensions of the panel, respectively; $\alpha_{\mathrm{i}}$ represents fixed country effects and $\varepsilon_{i t}$ is the error term. $\mathrm{x}_{\mathrm{it}}$ is a k-dimensional vector of time-varying control variables. The transition function $\mathrm{F}$ is a continuous function and depends on the threshold variable $\left(\mathrm{COR}_{\mathrm{it}}\right)$, while these extreme values are associated with regression coefficients $\beta_{0}$ and $\left(\beta_{0}+\beta_{1}\right)$. González et al. (2005) consider, following Granger and Teräsvirta (1993) for the time series STAR models, the following logistic transition function:

$$
\mathrm{F}\left(\pi_{\mathrm{it}}, \gamma, \mathrm{c}\right)=\left[1+\exp \left(-\gamma \prod_{j=1}^{\mathrm{m}}\left(\mathrm{COR}_{\mathrm{it}}-\mathrm{c}\right)\right)\right]^{-1} \text { with } \gamma>0 \text { and } \mathrm{c} 1 \leq \mathrm{c} 2 \leq \ldots \mathrm{cm}
$$

where $c_{j}=\left(c_{1}, \ldots, c_{m}\right)^{\prime}$, which is an $\mathrm{m}$-dimensional vector of parameters; the slope parameter $\gamma$ determines the smoothness of the transition. For $m=1$, the model has the two extreme regimes separating low and high values of it. For a higher value $\gamma$, the transition becomes rougher and the transition function $\mathrm{F}$ becomes the indicator function $\mathrm{F}\left(\mathrm{COR}_{\mathrm{it}}, \mathrm{c}\right)$. When $\gamma$ tends towards infinite, the indicator function $\mathrm{F}\left(\mathrm{COR}_{\mathrm{it}}, \mathrm{c}\right)$ $=1$ if event $\mathrm{COR}_{i t}>\mathrm{c}$ occurs, and the indicator function $\mathrm{F}\left(\mathrm{COR}_{\mathrm{it}}, \mathrm{c}\right)=0$, otherwise. When $\gamma$ is close to 0 , the transition function $F$ is constant. In that case, the PSTR converges towards the two-regime panel threshold regression (PTR) of Hansen (1999). With regard to the specifications of panel analysis or PTR, the main advantage 
of the PSTR is that it allows the public debt-corruption coefficient to vary according to the country and with the time. The PSTR model allows individuals move between groups and over time depending on changes in the threshold variable. The PSTR model also provides a parametric approach of the cross-country heterogeneity and of the time instability of the public debt-corruption coefficients, since these parameters change smoothly as a function of a threshold variable. González et al. (2005) propose the following specification procedure for PSTR:

(i) Test the linearity against the PSTR model; (ii) Parameter estimation; (iii) Test for number of transition functions. More specifically:

(i) Testing for linearity = testing the linearity in a PSTR model, Equation (1) can be done by testing $\mathrm{H}_{0}: \gamma=0$ or $\mathrm{H}_{0}: \beta_{0}=\beta_{1}$. However, in both cases, the test will be nonstandard since under $\mathrm{H}_{0}$ the PSTR model contains unidentified nuisance parameters. This issue is evident from the literature devoted to the time series threshold models (Hansen, 1999). Therefore, González et al. (2005), following Luukkonen et al. (1998) replace $\mathrm{F}$ in Equation (1) by its first-order Taylor expansion round $\gamma=0$ and obtain the auxiliary regression:

$\operatorname{Debt}_{\mathrm{it}}=\alpha_{\mathrm{i}}+\beta_{0} \mathrm{x}_{\mathrm{it}}+\beta_{1}{ }^{\prime} \mathrm{x}_{\mathrm{it}} \mathrm{COR}_{\mathrm{it}}+\ldots+\beta_{\mathrm{m}}{ }^{\prime} \mathrm{x}_{\mathrm{it}} \mathrm{COR}_{\mathrm{it}}{ }^{\mathrm{m}}+\varepsilon_{\mathrm{it}}$

where the parameter vectors $\left(\beta^{\prime}{ }_{1}, \ldots . ., \beta^{\prime}\right)$ are multiples of $\gamma$. Thus, testing $\mathrm{H}_{0}$ in Equation (1) is equivalent to testing the $\mathrm{H}_{0}{ }_{0}: \beta_{1}{ }_{1}+\ldots .+\beta^{\prime}{ }_{m}=0$ in Equation (3). This null hypothesis may be conveniently tested by a Wald and Likelihood ratio tests. If we denote $\mathrm{SSR}_{0}$ the panel sum of squared residuals under $\mathrm{H}_{0}$ (linear panel model with individual effects) and $\mathrm{SSR}_{1}$ the panel sum of squared residuals under $\mathrm{H}_{1}$ (PSTR model with two regimes), the Wald LM test can be written as:

$\mathrm{LM}_{\mathrm{W}}=\mathrm{N} \mathrm{T}\left(\mathrm{SSR}_{0}-\mathrm{SSR}_{1}\right) / \mathrm{SSR}_{0}$

where the Likelihood Ratio test can be written as:

$\mathrm{LR}=-2\left[\log \left(\mathrm{SSR}_{1}\right)-\log \left(\mathrm{SSR}_{0}\right)\right]$

(ii) Parameter estimation $=$ The parameters $\left(\beta_{0}{ }_{0}, \beta^{\prime}{ }_{1}, \gamma, c\right)$ in Equation (1) are estimated in two steps: (a) eliminate the individual effects by removing individualspecific means and (b) apply non-linear least squares (NLS) to the transformed data. The analysis applies NLS to determine the values of these parameters that minimize the concentrated sum of squared errors. While estimating the PSTR model, a practical issue that deserves special attention is the selection of starting values for $\gamma$ and $\mathrm{c}$, such that $\gamma>0, c_{i, \min }>\min \left(\mathrm{COR}_{\mathrm{it}}\right), \mathrm{c}_{\mathrm{j}, \max }<\max \left(\mathrm{COR}_{\mathrm{it}}\right), \mathrm{j}=1, \ldots ., \mathrm{m}$.

(iii) Testing for the number of transition functions $=$ The logic is similar when it comes to testing the number of transition functions (r) in the model or equivalently 
order of extreme regimes $(r+1)$. (González et al., 2005) propose a sequential approach by testing the null hypothesis of no remaining non-linearity in the transition function. In the PSTR framework, we assume that the linearity hypothesis is rejected. The issue is then to test whether there is one transition function $\left(\mathrm{H}_{0}: \mathrm{r}=1\right)$ or whether there are at least two transition functions $\left(\mathrm{H}_{0}: \mathrm{r}=2\right)$. Consider the model with $\mathrm{r}=2$ or three regimes:

$\operatorname{Debt}_{\text {it }}=\alpha_{\mathrm{i}}+\beta_{0}{ }^{\prime} \mathrm{x}^{\prime}{ }_{\mathrm{it}}+\beta_{1}{ }^{\prime} \mathrm{x}_{\mathrm{it}} \mathrm{F}_{1}\left(\mathrm{COR}_{\mathrm{it}}{ }^{1}, \gamma_{1}, \mathrm{c}_{1}\right)+\beta_{2}{ }^{\prime} \mathrm{x}_{\mathrm{it}} \mathrm{F}_{2}\left(\mathrm{COR}_{\mathrm{it}}{ }^{2}, \gamma_{2}, \mathrm{c}_{2}\right)+\varepsilon^{\prime}{ }_{\text {it }}$

We can replace the second transition function $F_{2}$ by its first-order Taylor expansion around $\gamma_{2}=0$, and then in testing linear constraints on the parameters. Therefore, the model in Equation (6) yields:

$\operatorname{Debt}_{i t}=\alpha_{i}+\beta_{0}{ }^{\prime} x^{\prime}{ }_{i t}+\beta_{1}{ }^{\prime} x_{i t} F_{1}\left(C C_{i t}{ }^{1}, \gamma_{1}, c_{1}\right)+\theta x_{i t} C O R_{i t}+\varepsilon^{\prime}{ }_{i t}$

The test of no remaining nonlinearity is simply defined by $\mathrm{H}_{0}: \theta=0$. Let us denote $\mathrm{SSR}_{0}$ the panel sum of squared residuals under $\mathrm{H}_{0}$, i.e. in a PSTR model with one transition function. Let us also denote $\mathrm{SSR}_{1}$ the sum of squared residuals of the transformed model in Equation (7). The testing procedure is then as follows: given a PSTR model with $\mathrm{r}=\mathrm{r} *$, we will test the null $\mathrm{H}_{0}: \mathrm{r}=\mathrm{r} *$ against $\mathrm{H}_{1}: \mathrm{r}=\mathrm{r} *+1 . \mathrm{If}_{0}$ is not rejected, the procedure ends. Otherwise, the null hypothesis $\mathrm{H}_{0}: \mathrm{r}=\mathrm{r} *+1$ is tested against $\mathrm{H}_{0}: r=r *+2$. The testing procedure continues until the first acceptance of $\mathrm{H}_{0}$.

For the robustness tests, we employ a public debt regression, which contains a quadratic interaction term as follows:

$\operatorname{Debt}_{\text {it }}=\alpha_{\mathrm{i}}+\delta^{\prime}{ }_{\mathrm{i}} \mathrm{x}_{\mathrm{it}}+\mathrm{x}_{0}{ }^{\prime} \mathrm{COR}_{\mathrm{it}}+\mathrm{x}_{1}{ }^{\prime} \mathrm{COR}_{\mathrm{it}}{ }^{2}+\mu^{\prime}{ }_{\mathrm{it}}$

The interaction term is included in Equation (8) to investigate non-linear public debt effects of the threshold variable. This allows us to detect whether, beyond a certain level, the threshold variable becomes more or less important in determining the marginal effect of corruption on the public debt.

\section{Empirical results}

For the test of linearity, we check whether the order $m$ is one. The results of the specification test in Equation (1) are presented in Table III. The findings show the pvalue of the Lagrange multiplier, as well as that of the Likelihood-ratio test for the null hypothesis of linearity against the alternative of logistic $(\mathrm{m}=1)$ or exponent $(\mathrm{m}=$ 2) PSTR specification. These findings document that the null hypothesis of linearity is rejected at the $1 \%$ significance level. Moreover, the rejection of linearity is stronger for $m=1$, therefore, the logistic specification $(m=1)$ is preferred to the exponent one $(\mathrm{m}=2)$. Therefore, there is a non-linear relationship between public debt and 
corruption across our countries in the sample. In that case, we employ the estimation of non-linear modeling approach by using the PSTR specification.

\section{[Insert Table III about here]}

Next, the analysis does a grid search to obtain threshold values c for the PSTR model. The optimal threshold value is one that minimizes the sequence of RSS in Equation (1). The search is performed from $1 \%$ to $90 \%$ for the sample, which yields 90 panel regressions of Equation (1). The minimization values of the RSS and AIC are reached at the semi-log of COR $=0.914$, which is converted to 5.34 for the CPI corruption index and at the semi-log of COR $=0.17$, which is converted to 1.19 for the CK index. The results illustrate that the estimated threshold value is 5.34 for the case of the CPI corruption index and 1.19 for the case of the CK index.

The estimation of PSTR needs testing no remaining linearity. We have strong evidence on the presence of one threshold in the model. In the case where the hypothesis without threshold $(\mathrm{r}=0)$ is rejected at the $1 \%$ significance for two tests, while in the case where the hypothesis with at least two thresholds $(r=2)$ is also rejected. In the former case, both the Lagrange Multiplier and the Likelihood Ratio tests are $6.37[\mathrm{p}$-value $=0.00]$ and $29.82[\mathrm{p}$-value $=0.00]$, respectively, while in the second case the results are 6.68[p-value $=0.00]$ and 30.96[0.00], respectively. These findings imply that the relationship between corruption and public debt has only one threshold, i.e. two regimes.

The analysis applies the PSTR non-linear least squares to data to eliminate the individual effects. Table IV reports the PSTR estimates. The results illustrate that the effect of corruption on public debt is non-linear. In particular, in the case of the CPI corruption index and for the low corruption regime, corruption is estimated to be 0.037 which is statistically significant at $10 \%$. For the case of high corruption regime, the corresponding coefficient is 0.095 and turns out to be statistically significant at $1 \%$. The results indicate that public debt responds faster to corruption in the high corruption regime compared to the low corruption regime. This result, perhaps, is explained by the fact that rent seeking increases at an increasing rate in the high corruption regime, leading to an increase in the need for public debt which causes public debt to respond faster to corruption in the high corruption regime.

In terms of the remaining control variables, the findings illustrate that the presence of a shadow economy, the government expenses to GDP ratio, the inflation rate, the interest payments on debt as a ratio of GDP and the ratio of military expenses 
to GDP ratio all exert a positive impact on the debt to GDP ratio. These findings are consistent with the previous literature. While Cooray et al. (2017) do not test for threshold effects, they find that both corruption and the shadow economy have a positive effect on the debt ratio, while Al-Marhubi (2000) shows that more corrupted countries face higher inflation. Similarly, Reinhart and Rogeff (2010) find that higher inflation can reduce the real value of the debt stock or alternatively, increase interest payments on debt, thereby increasing the stock of debt itsef. More corrupted governments could face higher debt servicing costs, implying that an increase in the rate of interest would lead to an increase in their public debt (Kaufmann, 2010). Similarly, if military expenditure is financed by borrowing, both public debt and debt servicing costs could increase (Cooray et al., 2017). By contrast, GDP per capita, the secondary school enrollment ratio and the ratio of tax revenues to GDP all have a negative effect on the debt to GDP ratio. The results remain consistently similar for the case of the CK corruption index.

\section{[Insert Table IV about here]}

The analysis is also concerned about the role of common shocks, that is, the recent (2008) financial crisis, in relevance to their impact on identifying the debt-corruption economy nexus. Financial and/or banking crises can often precede or accompany sovereign debt crises (Reinhart and Rogoff 2011). Large debts taken during periods of crisis are often due to falling revenues and rising debt (Reinhart and Rogoff 2009a, b). Crisis victims may need to reveal their financial position to public officials to access public services and this information can trigger extortion. Alternatively, crisis victims may be willing to pay bribes to public officials to get the service quicker or make sure it is of higher quality (Hunt, 2007). Thus, crises can contribute to the incidence of bribery and corruption leading to a change in the relationship between corruption and debt.

Based on the above discussion, we repeat the empirical analysis by incorporating a dummy variable that considers the role of the 2008 financial crisis in the nexus between public debt and corruption. This dummy variable takes the value of one at 2008 and zero otherwise. Once again, both the Lagrange Multiplier and the Likelihood-Ratio tests for the null hypothesis of linearity against the alternative of logistic $(\mathrm{m}=1)$ or exponent $(\mathrm{m}=2)$ PSTR specification are $7.11[\mathrm{p}$-value $=0.00]$ and $25.49[\mathrm{p}$-value $=0.00]$, respectively, in the former case and $7.47[\mathrm{p}$-value $=0.00]$ and $28.19[\mathrm{p}$-value $=0.00]$, respectively, in the latter case, denoting again that the null 
hypothesis of linearity is rejected at the $1 \%$ significance level. Once again, the rejection of linearity is stronger for $\mathrm{m}=1$, therefore, recommending the selection of the logistic specification and that there is a non-linear relationship between public debt and corruption across our countries in the sample, indicating that changes in the economic environment can lead to changes in the debt-corruption relationship. The grid search process also obtains threshold values $\mathrm{c}$, indicating that the minimization values this time are reached at the semi- $\log$ of $\mathrm{COR}=0.901$, which is converted to 5.22 for the CPI corruption index and at the semi-log of $\mathrm{COR}=0.15$, which is converted to 1.14 for the $\mathrm{CK}$ index. Moreover, testing of no remaining non-linearity indicates (again) the presence of strong evidence of one threshold in the model. In the case where the hypothesis without threshold $(r=0)$ is rejected at the $1 \%$ significance for two tests $(\mathrm{LM}$ test $=6.19[\mathrm{p}$-value $=0.00], \mathrm{LR}$ test $=26.30[\mathrm{p}$-value $=0.00])$, while in the case where the hypothesis with at least two thresholds $(r=2)$ is also rejected (LM test $=6.24[\mathrm{p}$-value $=0.00]$. LR test $=27.16[\mathrm{p}$-value $=0.00])$. These findings imply that the relationship between corruption and public debt has (again) only one threshold or two regimes.

Next, Table V reports the new PSTR estimates. The new results illustrate that the effect of corruption on public debt is (again) non-linear. In particular, in the case of the CPI corruption index and for the low corruption regime, corruption is estimated to be 0.032 which is statistically significant at $10 \%$. By contrast, for the case of high corruption regime, the corresponding coefficient is 0.083 which is statistically significant at $1 \%$. In terms of the remaining control variables, the findings provide robust evidence to those reported in Table IV. In terms of the financial crisis dummy variable, the estimates clearly illustrate that the crisis event had a positive and statistically significant impact on the debt to GDP ratio. Such findings seem to be consistent with those provided in the literature (Reinhart and Rogoff, 2009b; 2011). Once again, the results remain consistently similar for the case of the CK corruption index.

\section{[Insert Table V about here]}

This section repeats the empirical analysis by separating the overall sample into the developed and the developing country samples. According to Svensson (2005), corruption is rampant, mostly in the developing world and more prevalent in developing countries than in developed ones. Nevertheless, corruption appears to be present even in developed countries, especially in those with high-income inequality 
like the U.S., where the average voter has little impact in comparison to that of highincome voters (Ali and Saha, 2016). The Appendix depicts the split country samples.

Therefore, the empirical analysis is performed across the two country samples. Both the Lagrange Multiplier and the Likelihood-Ratio tests investigate the null hypothesis of linearity against the alternative of logistic $(\mathrm{m}=1)$ or exponent $(\mathrm{m}=2)$ PSTR specification across the two samples $(\mathrm{LM}=9.75[\mathrm{p}$-value $=0.00], \mathrm{LR}=32.84[\mathrm{p}$ value $=0.00]$ for developed countries and $\mathrm{LM}=6.58[\mathrm{p}$-value $=0.00), \mathrm{LR}=26.10[\mathrm{p}$ value $=0.00$ ] for developing countries). The findings display that the null hypothesis of linearity is rejected at the $1 \%$ significance level across both samples, while, the rejection of linearity is stronger for $m=1$, recommending the selection of the logistic specification in both country sample specifications. The grid search analysis provides relevant information about the transition parameter $\gamma$. More specifically, in the case of the developed country sample, the minimization values are reached at the semi-log of COR $=0.925$, which is converted to 5.40 for the CPI corruption index and at the semi-log of $\mathrm{COR}=0.21$, which is converted to 1.26 for the $\mathrm{CK}$ index, while in the case of the developing country sample, the respective values are reached at the semi$\log$ of $\mathrm{COR}=0.903$, which is converted to 5.25 for the CPI corruption index and at the semi-log of $\mathrm{COR}=0.13$, which is converted to 1.10 for the $\mathrm{CK}$ index

Table VI reports the PSTR estimates across the two country samples under investigation. The findings illustrate that the effect of corruption on public debt is (again) non-linear in both cases. In particular, in the case of the developed countries and in relevance to the CPI corruption index and for the low corruption regime, corruption is estimated to be 0.038 , which is statistically significant at $10 \%$. By contrast, for the case of high corruption regime, the corresponding coefficient is 0.099 , which is statistically significant at $1 \%$. Once again, the results remain consistently similar for the case of the CK corruption index. In terms of the developing country sample and the CPI corruption index, the findings for the low corruption regime indicate a coefficient of 0.022 , which is statistically insignificant, and for the high corruption regime, the coefficient turns out to be 0.071 , which is statistically significant at $1 \%$.

\section{[Insert Table VI about here]}

Finally, based on a reviewer's recommendation, as well as on literature's evidence (Sambanis, 2004; Khan, 2006), we repeat the analysis by dropping countries such as Albania, Angola, Burundi, Chad, Congo Democratic Republic, Congo Republic, 
Ghana, Liberia, Sierra Leone, Venezuela, Zambia and Zimbabwe that are considered as 'failed states' in terms of their corruption levels. The term 'state failure' is associated with the rent-seeking literature, which emphasizes the economic costs of state intervention. The message of this literature is that state failure, in the form of inefficient growth-retarding institutional issues, such as corruption and shadow economy, is often more costly to the economy in terms of rent-seeking and corruption costs than the market failures states are attempting to correct (Krueger, 1974; Rotberg, 2003). The problem in many less developed countries has not been only poor economic performance, but also a breakdown in the legitimacy and political viability of these states (Collier and Hoeffler, 1998). The new robustness results are reported in Table VII. Although the new findings provide robust evidence about the non-linear effect of corruption on public debt, the impact is lower in quantitative terms. More specifically, in the case of the CPI corruption index and for the low corruption regime, corruption is estimated to be 0.024 . For the case of high corruption regime, the corresponding coefficient is 0.057 . These findings indicate that public debt responds faster to corruption in the high corruption regime, but the speed is lower comparatively to the case that the failed states were included in the analysis. Moreover, in the case of the CK corruption index and for the low corruption regime, corruption is estimated to be 0.020 , but it turns out to be statistically insignificant, while for the case of high corruption regime, the corresponding coefficient is 0.041 .

\section{[Insert Table VII about here]}

\section{Conclusion}

This paper examined the (non-linear) relationship between corruption, government debt and the shadow economy in a panel of 120 countries, spanning the period 19992015. Using the Panel Smooth Transition Regression (PSTR) model of González et al. (2005), as well as two alternative measures of corruption, the empirical results documented that higher levels of corruption led to higher government debt. This result is consistent with that by Cooray et al. (2017). The results of the present study however, further indicated that the relationship between corruption and debt was nonlinear, while a strong threshold effect was present as well.

The results indicated that the estimated threshold value was 5.34 for the case of the CPI corruption index and 1.19 for the case of the CK index. Such findings suggest that every effort should be made to reduce corruption as it approaches these threshold levels. In particular, public debt appears to respond faster to a high corruption regime 
compared to a low corruption regime. The findings further indicated that an increase in the size of the shadow economy, government expenses, the inflation rate, interest payments on debt and military expenditure all increased the debt to GDP ratio. By contrast, an increase in GDP per capita, the secondary school enrollment ratio and the ratio of tax revenues to GDP led to a fall in the debt to GDP ratio. Finally, the results received robust support when the role of the 2008 financial crisis was explicitly considered, as well as in the case when two separate country samples were considered, i.e. developed vs developing countries. Finally, the results remain consistent even the analysis dropped a number of 'failed states', although the speed of adjustment of public debt to changes in corruption was much slower across both regimes.

The results carry the following policy implications: governments should aim to control both corruption and the size of the shadow economy if they really wish to reduce any high levels of their public debt. In particular, as debt levels respond faster to high corruption regimes, it is necessary that measures to reduce corruption are complemented by higher GDP per capita growth rates, enrolment rates and higher tax revenues.

\section{Appendix}

List of overall countries

Albania, Algeria, Angola, Argentina, Armenia, Australia, Austria, Bahrain, Bangladesh, Belarus, Belgium, Benin, Bolivia, Botswana, Brazil, Bulgaria, Burundi, Cambodia, Cameroon, Canada, Central African Republic, Chad, Chile, China, Colombia, Congo Democratic Republic, Congo Republic, Costa Rica, Cote d'Ivoire, Croatia, Cuba, Cyprus, Czech Republic, Denmark, Djibouti, Dominica, Dominican Republic, Ecuador, Egypt, El Salvador, Ethiopia, Fiji, Finland, France, FYROM, Gambia, Georgia, Germany, Ghana, Greece, Guatemala, Honduras, Hungary, India, Indonesia, Iran, Iraq, Ireland, Italy, Israel, Jamaica, Japan, Jordan, Kazakhstan, Kenya, Korea Republic, Kyrgyzstan, Laos, Latvia, Lebanon, Lesotho, Liberia, Libya, Lithuania, Luxemburg, Madagascar, Malawi, Malaysia, Maldives, Mauritania, Mauritius, Mexico, Mongolia, Namibia, Nepal, Netherlands, New Zealand, Nicaragua, Niger, Nigeria, Norway, Oman, Pakistan, Panama, Paraguay, Peru, Philippines, Poland, Romania, Russia, Senegal, Sierra Leone, South Africa, Sri Lanka, Sweden, Switzerland, Tajikistan, Thailand, Tunisia, Turkey, Uganda, Ukraine, 
United Arab Emirates, United Kingdom, United States, Uruguay, Venezuela, Yemen, Zambia, Zimbabwe.

\section{List of developed countries}

Argentina, Australia, Austria, Bahrain, Belgium, Brazil, Canada, Chile, China, Croatia, Cyprus, Czech Republic, Denmark, Finland, France, Germany, Greece, Hungary, Ireland, Italy, Israel, Japan, Korea Republic, Luxemburg, Netherlands, New Zealand, Norway, Poland, Russia, Sweden, Switzerland, United Arab Emirates, United Kingdom, United States.

\section{List of developing countries}

Albania, Algeria, Angola, Bangladesh, Benin, Bolivia, Botswana, Bulgaria, Burundi, Cambodia, Cameroon, Central African Republic, Chad, Colombia, Congo Democratic Republic, Congo Republic, Costa Rica, Cote d'Ivoire, Cuba, Djibouti, Dominica, Dominican Republic, Ecuador, Egypt, El Salvador, Ethiopia, Fiji, FYROM, Gambia, Georgia, Ghana, Guatemala, Honduras, India, Indonesia, Iran, Iraq, Jamaica, Jordan, Kazakhstan, Kenya, Kyrgyzstan, Laos, Latvia, Lebanon, Lesotho, Liberia, Libya, Lithuania, Madagascar, Malawi, Malaysia, Maldives, Mauritania, Mauritius, Mexico, Mongolia, Namibia, Nepal, Nicaragua, Niger, Nigeria, Oman, Pakistan, Panama, Paraguay, Peru, Philippines, Romania, Senegal, Sierra Leone, South Africa, Sri Lanka, Tajikistan, Thailand, Tunisia, Turkey, Uganda, Ukraine, Uruguay, Venezuela, Yemen, Zambia, Zimbabwe.

\section{References}

Abed, G. and Davoodi, H. (2002), "Corruption, structural reforms, and economic performance in the transition economies", in Abed, G.T. and Gupta, S. (Eds.), Governance, Corruption and Economic Performance, International Monetary Fund Publication Services, Washinghton, D.C.

Aidt, T.S. (2009), "Corruption, institutions, and economic development", Oxford Review of Economic Policy, Vol. 25, pp. 271-291.

Aidt, T.S. (2003), "Economic analysis of corruption: a survey”, Economic Journal, Vol. 113, pp. 632- 652.

Ali, M.S.B. and Saha, S. (2016), "Corruption and economic development", in: Economic Development in the Middle East and North Africa, Ali, M.S.B. and Saha, S. (Eds.), Springer, pp. 133-154. 
Al-Marhubi, F. (2000), "Corruption and inflation", Economics Letters, Vol. 66, pp. 199-202.

Andrews, D.W.K. (2005), "Cross-section regression with common shocks", Econometrica, Vol. 73, pp. 1551-1585.

Buehn, A. and Schneider, F. (2009), "Corruption and the shadow economy: a structural equation model approach”, IZA Discussion Paper, No. 4182.

Collier, P. and Hoeffler, A. (1998), "On the economic consequences of war", Oxford Economic Papers, Vol. 50, pp. 563-573.

Cooray, A., Dzhumashev, R. and Schneider, F. (2017), "How does corruption affect public debt? An empirical analysis", World Development, Vol. 90, pp. 115-127.

Del Monte, A. and Papagni, E. (2007), "The determinants of corruption in Italy: regional panel data analysis”, European Journal of Political Economy, Vol. 23, pp. 379-396.

Depken, C. and Lafountain, C. (2006), "Fiscal consequences of public corruption: empirical evidence from state bond ratings", Public Choice, Vol. 126, pp. 7585.

Diaz-Alejandro, C. (1985), "Good-bye financial repression, hello financial crash", Journal of Development Economics, Vol. 19, pp. 1-24.

Dreher, A., Kotsogiannis, C. and McCorriston, S. (2009), "How do institutions affect corruption and the shadow economy?", International Tax and Public Finance, Vol. 16, pp. 773-796.

Dreher, A. and Schneider, F. (2010), "Corruption and the shadow economy: an empirical analysis", Public Choice, Vol. 144, pp. 215-238.

Dzhumashev, R. (2014), "Corruption and growth: the role of governance, public spending and economic development”, Economic Modelling, Vol. 37, pp. 202215.

Friedman, E., Johnson, S., Kaufmann, D. and Zoido-Lobaton, P. (2000), "Dodging the grabbing hand: the determinants of unofficial activity in 69 countries", Journal of Public Economics, Vol. 76, pp. 459-493.

González, A., Teräsvirta, T. and Dijk, D.v. (2005), "Panel smooth transition regression models", Research Paper, No. 165, Stockholm School of Economics.

Gupta, S., De Mello, L. and Sharan, R. (2001), “Corruption and military spending”, European Journal of Political Economy, Vol. 17, pp. 749-777.

Haque, N.U., Pesaran, M.H. and Sharma, S. (1999), "Neglected heterogeneity and dynamics in cross-country savings regressions", Mimeo. 
Hansen, B. (1999), “Threshold effects in non-dynamic panels: estimation, testing and inference", Journal of Econometrics, Vol. 93, pp. 345-368.

Hunt, J. (2007), "How corruption hits people when they are down", Journal of Development Economics, Vol. 84, pp. 574-589.

Johnson, E. (1975), “An economic analysis of corrupt government, with special application for less developed countries", Kyklos, Vol. 28, pp. 47-61.

Justesen, M. and Bjornskov, C. (2014), "Exploiting the poor: bureaucratic corruption and poverty in Africa", World Development, Vol. 58, pp. 106-115.

Kaufmann, D. (2010), "Can corruption adversely affect public finances in industrialized countries?", Working Paper, The Brookings Institution, Washington, DC.

Kaufmann, D., Kraay, A. and Mastruzzi, M. (2013), World Bank, Available at: http://info.worldbank.org/governance/wgi/index.aspx.

Khan, M.H. (2006). "Governance, economic growth and development since the 1960s”, Background paper for World Economic and Social Survey 2006.

Krueger, A. (1974), "The political economy of the rent-seeking society", American Economic Review, Vol. 64, pp. 291-303.

Lambsdorff, J.G. (2003), "How corruption affects productivity?”, Kyklos, Vol. 56, pp. 457-474.

Leff, N. (1964), "Economic development through bureaucratic corruption", American Behavioral Scientist, Vol. 8, pp. 8-14.

Liu, F.T. (1996), “Three aspects of corruption”, Contemporary Economic Policy, Vol. 14 , pp. 26-29.

Luukkonen, R., Saikkonen, P. and Teräsvirta, T. (1998), “Testing linearity against smooth transition autoregressive models", Biometrika, Vol. 75, pp. 491-499.

Maki, D. (2010), "An alternative procedure to test for cointegration in STAR models". Mathematics and Computers in Simulation, Vol. 80, pp. 999-1006.

Mauro, P. (1998), "Corruption and the composition of government expenditure", Journal of Public Economics, Vol. 69, pp. 263-279.

Mendez, F. and Sepulveda, F. (2006), "Corruption, growth and political regimes: cross country evidence”, European Journal of Political Economy, Vol. 22, pp. 82-98.

Meon, P.G. and Weill, L. (2010), "Is corruption an efficient grease?", World Development, Vol. 38, pp. 244-259. 
Mistry, J. and Jalal, A. (2012), “An empirical analysis of the relationship between egovernment and corruption", The International Journal of Digital Accounting Research, Vol. 12, pp. 145-176.

Mo, P. (2001), "Corruption and economic growth", Journal of Comparative Economics, Vol. 29, pp. 66-79.

Montinolla, G. and Jackman, R. (2002), "Sources of corruption: a cross country study”, British Journal of Political Science, Vol. 32, pp. 147-170.

Murphy K., Shleifer, A. and Vishny, R. (1993), "Why is rent-seeking so costly for growth?", American Economic Review Papers and Proceedings of the Hundred and Fifth Annual Meeting, Vol. 83, pp. 409-414.

Newey, W.K. and West, K.D. (1994), “Automatic lag selection in covariance matrix estimation", Review of Economic Studies, Vol. 61, pp. 631-653.

Pathak, R.D., Singh, G., Belwal, R., Naz, R. and Smith, R.F.I. (2008), “E-governance, corruption and public service delivery: a comparative study of Fiji and Ethiopia”, Journal of Administration and Governance, Vol. 3, pp. 65-79.

Pesaran, M. (2007), “A simple panel unit root test in the presence of cross-section dependence", Journal of Applied Econometrics, Vol. 22, pp. 265-312.

Pesaran, M.H. (2004), "General diagnostic tests for cross section dependence in panels", Cambridge Working Papers in Economics, No. 435 and CESifo Working Paper, No. 1229.

Phillips, P.C.B. and Sul, D. (2003), "Dynamic panel estimation and homogeneity testing under cross section dependence", Economic Journal, Vol. 6, pp. 217259.

Reinhart, C.M. and Rogoff, K.S. (2011), "From financial crash to debt crisis", American Economic Review, Vol. 101, pp. 1676-1706.

Reinhart, C.M. and Rogoff, K.S. (2009a), This Time is Different: Eight Centuries of Financial Folly, Princeton, NJ: Princeton University Press.

Reinhart, C.M. and Rogoff, K.S. (2009b), "The aftermath of financial crises", American Economic Review, Vol. 99, pp. 466-472.

Rotberg, R. (2003), State Failure and State Weakness in a Time of Terror, Washington, D.C.: Brookings Institute Press.

Sambanis, N. (2004), "What is a civil war? Conceptual and empirical complexities of an operational definition", Journal of Conflict Resolution, Vol. 48, pp. 814-858.

Schneider, F. and Enste, D. (2000), "Shadow economies: size, causes, and consequences", Journal of Economic Literature, Vol. 38, pp. 77-114. 
Schneider, F., Buehn, A. and Montenegro, C. (2010), "Shadow economies all over the world: new estimates for 162 countries from 1999-2007”, World Bank Policy Research, Working Paper, No. 5356.

Smith, P. (1994), "Assessing the size of the underground economy: Canadian Statistics", Canadian Economic Observer, Catalogue 11-010.

Smith, V., Leybourne, S. and Kim, T.H. (2004), "More powerful panel unit root tests with an application to the mean reversion in real exchange rates", Journal of Applied Econometrics, Vol. 19, pp. 147-170.

Svensson, J. (2005), "Eight questions about corruption", Journal of Economic Perspectives, Vol. 19, pp. 19-42.

Tanzi, V. (1998), "Corruption around the world: causes, consequences, scope and cures", IMF Staff Papers, Vol. 45, pp. 559-594.

Tanzi, V. and Davoodi, H. (2002), "Corruption, public investment and growth", in Abed, T.G. and Gupta, S. (Eds.) Governance, Corruption and Economic Performance, International Monetary Fund, Washinghton, DC, pp. 280-299.

Velasco, A. (1987), "Financial crises and balance of payments crises: a simple model of the Southern cone experience", Journal of Development Economics, Vol. 27, pp. 263-283.

Wedeman, A. (1997), "Looters, rent-scrapers, and dividend-collectors: corruption and growth in Zaire, South Korea, and the Philippines", Journal of Developing Areas, Vol. 31, pp. 457-478.

Wei, S. (2001), "Corruption in economic transition and development", UNECE Spring Seminar, Geneva.

Wei, S. (2000), "How taxing is corruption on international investors?", Review of Economics and Statistics, Vol. 82, pp. 1-11. 
Table I.

Descriptive statistics

\begin{tabular}{lcccr}
\hline Variables & Mean & SD & Min & Max \\
\cline { 1 - 4 } Corruption Perception Index (CPI) & 6.96 & 1.08 & 0.16 & 8.94 \\
Corruption Kaufmann et al. (CK) & 3.41 & 0.95 & 0.42 & 4.61 \\
Shadow economy (\% of GDP) & 36.73 & 10.93 & 11.4 & 66.18 \\
Government debt (\% of GDP) & 63.49 & 50.48 & 1.43 & 275.41 \\
Debt servicing ratio (\% of GDP) & 3.83 & 33.81 & 1.04 & 87.52 \\
Government expenses to GDP & 14.28 & 6.32 & 2.01 & 67.81 \\
GDP per capita (constant 2005 \$) & $1,649.86$ & $1,732.14$ & 78.43 & $9,578.44$ \\
Secondary school enrollment (\%) & 60.14 & 26.52 & 4.97 & 117.82 \\
Inflation & 26.19 & 177.93 & -5.14 & 239.18 \\
Tax revenues to GDP & 14.21 & 6.35 & 0.10 & 60.47 \\
$\begin{array}{l}\text { Interest payments on debt } \\
\text { to GDP }\end{array}$ & 11.49 & 12.82 & 5.61 & 98.72 \\
Military expenses to GDP & 2.29 & 2.36 & 0.08 & 41.63 \\
No. of observations = 2,040 & & & & \\
\hline
\end{tabular}


Table II.

Panel unit root tests

\begin{tabular}{|c|c|c|c|c|c|c|}
\hline Variables & $\begin{array}{l}\text { Pesaran } \\
\text { CIPS }\end{array}$ & $\begin{array}{l}\text { Pesaran } \\
\text { CIPS* }\end{array}$ & $\begin{array}{l}\text { Smith et } \\
\text { al.-t-test }\end{array}$ & $\begin{array}{l}\text { Smith et } \\
\text { al.-LM-test }\end{array}$ & $\begin{array}{l}\text { Smith et } \\
\text { al.-max-test }\end{array}$ & $\begin{array}{l}\text { Smith et } \\
\text { al.-min-test }\end{array}$ \\
\hline CPI & -1.18 & -1.25 & -1.26 & 2.84 & -1.31 & 1.35 \\
\hline$\Delta \mathrm{CPI}$ & $-5.72 * * *$ & $-5.96 * * *$ & $-5.88 * * *$ & $21.35 * * *$ & $-6.10 * * *$ & $6.27 * * *$ \\
\hline $\mathrm{CK}$ & -1.22 & -1.29 & -1.25 & 2.79 & -1.35 & 1.39 \\
\hline$\Delta \mathrm{CK}$ & $-5.68 * * *$ & $-5.84 * * *$ & $-5.75 * * *$ & $20.36 * * *$ & $-5.92 * * *$ & $6.18 * * *$ \\
\hline Shadow economy & -1.20 & -1.32 & -1.36 & 2.94 & -1.40 & 1.42 \\
\hline$\Delta$ Shadow economy & $-6.11 * * *$ & $-6.58 * * *$ & $-6.31 * * *$ & $21.15 * * *$ & $-6.58 * * *$ & $6.67 * * *$ \\
\hline Government debt & -1.29 & -1.37 & -1.32 & 2.83 & -1.39 & 1.47 \\
\hline$\Delta$ Government debt & $-6.14 * * *$ & $-6.35 * * *$ & $-6.17 * * *$ & $20.84 * * *$ & $-6.38 * * *$ & $6.83 * * *$ \\
\hline Debt servicing ratio & -1.25 & -1.31 & -1.39 & 2.71 & -1.44 & 1.50 \\
\hline$\Delta$ Debt servicing ratio & $-5.93 * * *$ & $-6.24 * * *$ & $-6.28 * * *$ & $21.05 * * *$ & $-6.45 * * *$ & $6.74 * * *$ \\
\hline Government expenses & -1.33 & -1.40 & -1.35 & 2.77 & -1.43 & 1.49 \\
\hline$\Delta$ Government expenses & $-6.10 * * *$ & $-6.48 * * *$ & $-6.20 * * *$ & $21.24 * * *$ & $-6.31 * * *$ & $6.61 * * *$ \\
\hline GDP per capita & -1.36 & -1.42 & -1.35 & 2.82 & -1.45 & 1.53 \\
\hline$\Delta$ GDP per capita & $-6.24 * * *$ & $-6.44 * * *$ & $-6.32 * * *$ & $21.14 * * *$ & $-6.64 * * *$ & $6.78 * * *$ \\
\hline School enrollment & -1.29 & -1.37 & -1.33 & 2.95 & -1.39 & 1.48 \\
\hline$\Delta$ School enrollment & $-5.92 * * *$ & $-6.31 * * *$ & $-6.15 * * *$ & $21.38 * * *$ & $-6.38 * * *$ & $6.85 * * *$ \\
\hline Inflation & $-6.14 * * *$ & $-6.58 * * *$ & $-6.36 * * *$ & $21.95 * * *$ & $-6.69 * * *$ & $6.81 * * *$ \\
\hline Tax revenues & -1.37 & -1.44 & -1.35 & 2.80 & -1.41 & 1.45 \\
\hline$\Delta \mathrm{Tax}$ revenues & $-6.04 * * *$ & $-6.38 * * *$ & $-6.27 * * *$ & $20.74 * * *$ & $-6.53 * * *$ & $6.70 * * *$ \\
\hline Interest payments & -1.28 & -1.39 & -1.35 & 2.85 & -1.46 & 1.51 \\
\hline$\Delta$ Interest payment & $-5.92 * * *$ & $-6.22 * * *$ & $-6.09 * * *$ & $20.55 * * *$ & $-6.38 * * *$ & $6.58 * * *$ \\
\hline Military expenses & -1.24 & -1.28 & -1.25 & 2.92 & -1.34 & 1.38 \\
\hline$\Delta$ Military expenses & $-6.28 * * *$ & $-6.40 * * *$ & $-6.31 * * *$ & $21.06 * * *$ & $-6.46 * * *$ & $6.74 * * *$ \\
\hline
\end{tabular}

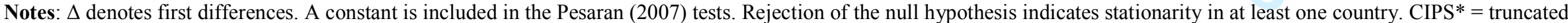

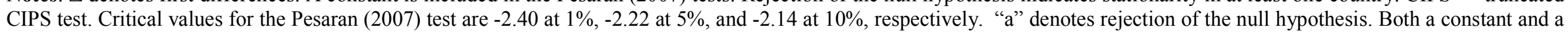


time trend are included in the Smith et al. (2004) tests. Rejection of the null hypothesis indicates stationarity in at least one country. For both tests the results are reported at lag $=4$. The null hypothesis is that of a unit root. $* *: \leq 0.01$. 
Table III.

Tests of linearity

Test $\mathrm{m}=1 \quad \mathrm{~m}=2$

CPI corruption index

Lagrange multiplier (LM)

Likelihood ratio (LR)

CK corruption index

Lagrange multiplier (LM)

Likelihood ratio (LR)

$\begin{array}{rr}7.39 * * * & 1.09 \\ 28.93^{* * *} & 4.38 \\ & \\ 7.85^{* * *} & 1.03 \\ 30.71 * * * & 3.72\end{array}$

Notes: ${ }^{* * *}: \mathrm{p} \leq 0.01 . \mathrm{H}_{0}$ : Linear model; $\mathrm{H}_{1}$ : PSTR model with $\mathrm{m}=1$ or $\mathrm{m}=2$. 
Table IV.

PSTR estimates (Dependent variable: public debt as percent of GDP)

\begin{tabular}{llc}
\hline Variables & Coefficient & p-value \\
\hline CPI corruption index & & \\
Shadow economy & $0.294^{* * *}$ & 0.00 \\
Government expenses to GDP & $0.127^{* * *}$ & 0.01 \\
GDP per capita & $-0.176^{* * *}$ & 0.00 \\
Secondary enrollment ratio & $-0.083^{*}$ & 0.08 \\
Inflation rate & $0.027^{* * *}$ & 0.00 \\
Tax revenues as a ratio of GDP & $-0.308^{* * *}$ & 0.00 \\
Interest payments on debt & & \\
as a ratio of GDP & $0.195^{* * *}$ & 0.00 \\
Military expenses to GDP & $0.248^{* *}$ & 0.05 \\
Corruption & $0.037^{*}$ & 0.09 \\
Corruption $* \mathrm{~F}_{1}\left(\mathrm{COR} \mathrm{it}_{\mathrm{it}}, \gamma, \mathrm{c}\right)$ & $0.095^{* * *}$ & 0.00 \\
& & \\
Transition parameters & & \\
$\mathrm{c}$ & 5.34 & \\
$\gamma$ & 2.78 & \\
R-squared & 0.63 & \\
Adjusted R-squared & 0.55 &
\end{tabular}

CK corruption index

Shadow economy

$0.279 * * * \quad 0.00$

Government expenses to GDP

$0.114 * * *$

0.01

GDP per capita

$-0.158 * * * \quad 0.00$

Secondary enrollment ratio

$-0.069 * *$

0.05

Inflation rate

$0.023 * * * \quad 0.00$

Tax revenues as a ratio of GDP

$-0.285 * * *$

0.00

Interest payments on debt

as a ratio of GDP

$0.179 * * * \quad 0.00$

Military expenses to GDP

$0.236^{* *}$

0.05

Corruption

$0.031^{*}$

0.10

Corruption $* \mathrm{~F}_{1}\left(\mathrm{COR}_{\mathrm{it}}, \gamma, \mathrm{c}\right)$

$0.088^{* * *}$

0.00

Transition parameters

c

1.19

$\gamma$

R-squared

3.12

Adjusted R-squared

0.54

0.49

Note: $*: \mathrm{p} \leq 0.10, * *: \mathrm{p} \leq 0.05, * * *: \mathrm{p} \leq 0.01$. 
Table V.

PSTR estimates (Dependent variable: public debt as percent of GDP-the model with the financial crisis dummy)

\begin{tabular}{lll}
\hline Variables & Coefficient & p-value
\end{tabular}

\section{CPI corruption index}

Shadow economy

$0.261 * * *$

0.00

Government expenses to GDP

$0.115 * * *$

0.01

GDP per capita

$-0.158^{* * *}$

0.00

Secondary enrollment ratio

$-0.069^{*}$

0.10

Inflation rate

$0.021 * *$

0.03

Tax revenues as a ratio of GDP

$-0.286 * * *$

0.00

Interest payments on debt

as a ratio of GDP

$0.169 * * *$

0.00

Military expenses to GDP

Corruption

$0.235^{* *}$

0.05

$0.032^{*}$

0.10

Corruption $* \mathrm{~F}_{1}\left(\mathrm{COR}_{\mathrm{it}}, \gamma, \mathrm{c}\right)$

$0.083 * * *$

0.00

Financial crisis dummy

$0.139 * * *$

0.00

Transition parameters

c

5.22

$\gamma$

R-squared

2.58

0.58

Adjusted R-squared

0.50

\section{CK corruption index}

Shadow economy

Government expenses to GDP

GDP per capita

Secondary enrollment ratio

Inflation rate

Tax revenues as a ratio of GDP

Interest payments on debt

as a ratio of GDP

Military expenses to GDP

Corruption

Corruption $* \mathrm{~F}_{1}\left(\mathrm{COR}_{\mathrm{it}}, \gamma, \mathrm{c}\right)$

Financial crisis dummy

$\begin{array}{ll}0.244 * * * & 0.00 \\ 0.102 * * * & 0.01 \\ -0.136 * * * & 0.00 \\ -0.061 * * & 0.05 \\ 0.017 * * & 0.04 \\ -0.259 * * * & 0.00 \\ & \\ 0.145 * * * & 0.00 \\ 0.201 * * & 0.05 \\ 0.025 * & 0.10 \\ 0.071 * * * & 0.01 \\ 0.164 * * * & 0.00\end{array}$

Transition parameters

c

1.14

$\gamma \quad 3.01$

R-squared $\quad 0.51$

Adjusted R-squared $\quad 0.44$

Notes: $*: \mathrm{p} \leq 0.10, * *: \mathrm{p} \leq 0.05, * * *: \mathrm{p} \leq 0.01$. 
Table VI.

PSTR estimates (Dependent variable: public debt as percent of GDP- developed and developing country samples)

Variables Coefficient $\quad$ p-value

Developed countries
CPI corruption index

Shadow economy

$0.265^{* * *}$

0.00

Government expenses to GDP

$0.148 * * *$

0.00

GDP per capita

$-0.199 * * *$

0.00

Secondary enrollment ratio

$-0.105^{* *}$

0.03

Inflation rate

$0.011^{*}$

0.07

Tax revenues as a ratio of GDP

$-0.329 * * *$

0.00

Interest payments on debt

as a ratio of GDP

$0.238 * * * \quad 0.00$

Military expenses to GDP

Corruption

$0.295 * * *$

0.00

$0.038^{*}$

0.10

Corruption $* \mathrm{~F}_{1}\left(\mathrm{COR}_{\mathrm{it}}, \gamma, \mathrm{c}\right)$

$0.099 * * *$

0.00

Transition parameters

c

5.40

$\gamma$

R-squared

2.79

0.69

Adjusted R-squared

0.61

\section{CK corruption index}

Shadow economy

Government expenses to GDP

$0.253 * * *$

0.00

$0.139 * * * \quad 0.00$

GDP per capita

$-0.183^{* * *} \quad 0.00$

Secondary enrollment ratio

$-0.075 * *$

0.04

Inflation rate

$0.012^{*}$

0.06

Tax revenues as a ratio of GDP

$-0.311^{* * *}$

0.00

Interest payments on debt

as a ratio of GDP

$0.185^{* * *}$

0.00

Military expenses to GDP

$0.255^{* * *}$

0.01

Corruption

$0.035^{*}$

0.08

Corruption $* \mathrm{~F}_{1}\left(\mathrm{COR}_{\mathrm{it}}, \gamma, \mathrm{c}\right)$

$0.091 * * *$

0.00

Transition parameters

c

1.26

$\gamma$

R-squared

3.38

0.63

Adjusted R-squared

0.59

Developing countries

CPI corruption index

Shadow economy

$0.315^{* * *}$

0.00

Government expenses to GDP

$0.109^{* * *}$

0.01

GDP per capita

$-0.161 * * *$

0.00

Secondary enrollment ratio

$-0.064 * *$

0.04

Inflation rate

$0.038^{*}$

0.06 
Table VI (continued).

\begin{tabular}{lc}
\hline Tax revenues as a ratio of GDP & -0.25 \\
Interest payments on debt & \\
as a ratio of GDP & 0.156 \\
Military expenses to GDP & 0.237 \\
Corruption & 0.046 \\
Corruption $* \mathrm{~F}_{1}\left(\mathrm{COR}_{\mathrm{it}}, \gamma, \mathrm{c}\right)$ & 0.108 \\
& \\
Transition parameters & \\
$\mathrm{c}$ & 5.25 \\
$\gamma$ & 2.48 \\
R-squared & 0.58 \\
Adjusted R-squared & 0.54
\end{tabular}

\section{CK corruption index}

Shadow economy

$0.311 * * * \quad 0.00$

Government expenses to GDP

$0.116^{* * *}$

0.00

GDP per capita

$-0.156^{* * *} \quad 0.00$

Secondary enrollment ratio

$-0.058 * *$

0.05

Inflation rate

$0.035^{*}$

0.07

Tax revenues as a ratio of GDP

$-0.243 * * *$

0.00

Interest payments on debt

as a ratio of GDP

$0.148^{* * *}$

0.00

Military expenses to GDP

$0.231 * * *$

0.01

Corruption

$0.042^{*}$

0.08

Corruption $* \mathrm{~F}_{1}\left(\mathrm{COR}_{\mathrm{it}}, \gamma, \mathrm{c}\right)$

$0.097 * * *$

0.01

Transition parameters

c

1.10

$\gamma$

R-squared

2.95

Adjusted R-squared

0.55

0.50

Notes: ${ }^{*}: \mathrm{p} \leq 0.10,{ }^{* *}: \mathrm{p} \leq 0.05, * * *: \mathrm{p} \leq 0.01$ 
Table VII.

PSTR estimates (Dependent variable: public debt as percent of GDP)-The sample excludes a number of 'failed states'

Variables Coefficient p-value

CPI corruption index

Shadow economy

$0.219 * * * \quad 0.00$

Government expenses to GDP

$0.148 * * *$

0.00

GDP per capita

$-0.239 * * *$

0.00

Secondary enrollment ratio

$-0.117 * * *$

0.01

Inflation rate

$0.013^{* *}$

0.04

Tax revenues as a ratio of GDP

$-0.274 * * *$

0.00

Interest payments on debt

as a ratio of GDP

$0.169 * * * \quad 0.00$

Military expenses to GDP

Corruption

$0.216^{*}$

0.06

$0.024^{*}$

0.10

Corruption $* \mathrm{~F}_{1}\left(\mathrm{COR}_{\mathrm{it}}, \gamma, \mathrm{c}\right)$

$0.057 * * *$

0.01

Transition parameters

c

4.85

$\gamma$

R-squared

2.19

0.69

Adjusted R-squared

0.58

\section{CK corruption index}

Shadow economy

Government expenses to GDP

GDP per capita

Secondary enrollment ratio

Inflation rate

Tax revenues as a ratio of GDP

Interest payments on debt

as a ratio of GDP

Military expenses to GDP

Corruption

Corruption $* \mathrm{~F}_{1}\left(\mathrm{COR}_{\mathrm{it}}, \gamma, \mathrm{c}\right)$

$0.226 * * *$

0.00

$0.129 * * * \quad 0.00$

$-0.186 * * * \quad 0.00$

$-0.087^{* *} \quad 0.04$

$0.019 * * * \quad 0.01$

$-0.262 * * * \quad 0.00$

Transition parameters

c

$0.147 * * * \quad 0.00$

$0.195^{*}$

0.06

0.020

0.12

$0.041^{* *}$

0.04

1.06

$\gamma$

R-squared

2.74

0.58

Adjusted R-squared

0.51

Note: ${ }^{*}: \mathrm{p} \leq 0.10,{ }^{* *}: \mathrm{p} \leq 0.05,{ }^{* * *}: \mathrm{p} \leq 0.01$. 


\title{
New evidence on corruption and government debt from a global country panel: a non-linear panel long-run approach
}

\author{
Emmanuel Apergis \\ University of Kent, $U K$ \\ ea350@kent.ac.uk
}

Nicholas Apergis

University of Piraeus, Greece

napergis@unipi.gr 